\title{
RETRACTED: RCE-Kmeans Method for Data Clustering
}

\author{
Izmy Alwiah Musdar ${ }^{\mathrm{a}, 1}$, Azhari ${ }^{\mathrm{a}, 2}$ \\ ${ }^{a}$ Program Studi S2 Ilmu Komputer, FMIPA UGM, Yogyakarta \\ b Jurusan Ilmu Komputer dan Elektronika, FMIPA UGM, Yogyakarta \\ ${ }^{1}$ izmyalwiah@gmail.com*, 2arisn.softcomp@gmail.com
}

Article history:

Retraction notice to "RCE-Kmeans Method for Data Clustering ", Vol 1, No 2, pp. 107114, July 2015

DOI: http://dx.doi.org/10.26555/ijain.v1i2.38

Retracted on August 21, 2017
Following a rigorous, carefully concerns and considered review of the article published in International Journal of Advances in Intelligent Informatics to article entitled "RCE-Kmeans Method for Data Clustering" Vol 1, No 2, pp. 107-114, July 2015, DOI: http://dx.doi.org/10.26555/ijain.v1i2.38.

This paper has been found to be in violation of the International Journal of Advances in Intelligent Informatics Publication principles and has been retracted. The article contained redundant material, the editor investigated and found that the paper published in Indonesian Journal of Computing and Cybernetics Systems, Vol. 9, No. 2 (July 2015), pp. 157-166, DOI: http://doi.org/10.22146/ijccs.7544, entitled "Metode RCE-Kmeans untuk Clustering Data".

The document and its content has been removed from International Journal of Advances in Intelligent Informatics, and reasonable effort should be made to remove all references to this article.

Copyright $\odot 2017$ International Journal of Advances in Intelligent Informatics. All rights reserved. 